\title{
Attitude of Parents toward Female-Child Secondary Education in Sokoto State, Nigeria: Implications for Counselling
}

\author{
Dr. (Mrs.) Anna Onoyase \\ Department of Guidance and Counselling, \\ Delta State University, Abraka, Nigeria
}

\section{Doi: 10.2478/jesr-2018-0012}

\begin{abstract}
The study was set out to investigate the attitude of parents toward female-child secondary education in Sokoto State, Nigeria. One research question and one hypothesis were formulated to guide the study. The study is a descriptive survey and made use of ex-post facto design. The researcher made use of purposive sampling technique to select 270 parents from the urban and 270 parents from the rural areas of Sokoto State. The researcher made use of an instrument adapted from that of Terhemba and Umaru 2015. The instrument is known as "Attitude of Parents Toward Female Child Secondary Education Questionnaire" (APTFCSEQ). The APTFCSEQ had a reliability coefficient of 0.81 . The instrument had facial and content validity. It also had language appropriateness. The researcher used four (4) research Assistants to administer 540 copies of the questionnaire on the respondents. All the 540 copies of the questionnaire were retrieved showing 100 percent return rate. The data generated from the field were collated and the mean score analysis for the 15 items was carried out in order to provide answer to the research question raised in the study. 2.5 was chosen as the benchmark for either disagreeing or agreeing with each of the 15 items. The t-test statistics was used to test the hypothesis at 0.05 level of significance. The investigation found out that parents in Sokoto State have shown unfavourable attitude toward female-child secondary education. It found out that there is no significant difference between parents in the urban and rural areas in their attitude toward female-child secondary education. This finding has shown that whether the parent is in urban or rural area, all of them have expressed their opinion in the same direction. One of the recommendations of the study is that parents in Sokoto State should show favourable attitude toward female-child secondary education.
\end{abstract}

Keywords: Attitude, Parents, Female-Child and Secondary Education

\section{Introduction}

The importance of education in building an egalitarian society cannot be overemphasized. Probably, this was why the National Policy on Education (2016:6) states that every Nigerian child shall have a right to equal educational opportunities irrespective of any real or imagined disabilities, each according to his or her ability. This position appears to contradict the attitude which some parents have toward the education of their female-child. For instance, Kamaldeem, Buhari and Parakoyi (2012:2) have reported the glaring imbalance against girls in enrolment, attendance and completion rates in all levels of education in Nigeria particularly in northern parts of the country due to a variety of socio-cultural and religious factors. Terhemba and Umaru (2015:11) have stressed that female-child access to basic education especially in northern states of Nigeria appear to be something of great concern. They maintained that the ratio of boys to girls' enrolment, retention and completion of secondary education particularly in Yobe state remains alarmingly low. This is because only 20 percent of women in North-Eastern Nigeria were literate.

Ekijiuba (2011:175) stated that the issue of poverty has further aggravated the situation of 
girls' lack of access to education because some parents when faced with scarce resources, choose to educate boys rather than girls. Traditional beliefs and parental poverty have been found to foster negative attitude which limit parents' support for girl-child education. As far as Olomukoro and Omiunu (2011) are concerned, other hindrances to girl child education in Nigeria include cultural inhibitions, erroneous interpretations of religious injunctions, traditional practices, early betrothal of girls in marriage, gender insensitivity to educational environments, social preference for the male child and overburdening of the girl-child with household labour.

Ekejiuba (2011) has maintained that women in Nigeria are hit with poverty than the men because of disparity in education and the prevalence of early marriage that tend further to impoverish women and subject them to discrimination. Umoh and Atakpa (2014) asserted that generally because of gender discrimination and cultural barriers, the girl-child was not allowed the opportunity to go to school early in Africa. They were patted, loved and kept back at home to cook, marry, bear children, keep the house and serve the men.

Ambreen and Mohyuddin (2013) asserted that generally, in Pakistan, parents prefer their sons to go to school over their daughters because they are supposed to be the helping hand for the parents. They stressed that parents tend to think that whatever they spent on sons is an investment whereas spending over daughters is a waste because they are considered as liabilities.

Terhemba and Umaru (2015) carried out a study on the evaluation of parents' attitude toward girl-child enrolment, retention and completion of secondary school in Yobe State, Nigeria. The researchers used the instrument known as Attitude on Girl-Child Education questionnaire to gather data from the field. The questionnaire had Cronbach alpha reliability of .823. The instrument was administered on 500 parents and all questionnaire were retrieved showing one hundred percent return rate. The researchers used percentage and t-test to analyse the data and findings showed that:

1. Attitude of parents towards girl-child enrolment, retention and completion of secondary schools in Yobe State was not positive.

2. There is no significant difference between the attitude of rural and urban parents towards girl-child enrolment, retention and completion of secondary school in Yobe State.

Kamaldeen, Buhari and Parakoyi (2012) in their study found out that school enrolment pattern of female children by calculation constituted $69.5 \%$ of children that dropped out of schools. Some of the reasons advanced were lack of money, running of errands for parents, early marriage, truancy in school, hawking activities and early pregnancy. Samal (2012) undertook the study of parents' attitude towards schooling and education of children in India, and found out that the attitude of parents to girl-child education was not favourable. The study equally found out that, inspite of the government's endeavours in providing free education to all, the attitude of parents to girl-child education was not found to be highly favourable. The attitude of male and female parents with respect to schooling of the girl-child was found not to be significantly different.

Okobia and Ekejiuba (2015) investigated parental attitudes and girl-child education in Edo State Nigeria. A sample of 450 respondents randomly selected from Benin metropolis participated in the study. The instrument used for collection of data was tagged, "Parental Attribute Towards Girl-Child Education". The data collected were subjected to statistical analysis using t-test and analysis of variance. Hypotheses were tested at 0.05 level of significance. Findings showed that parents have positive attitude towards girl-child education. Parents from southern parts of Nigeria residing in Benin metropolis were more disposed to girl-child education than those from northern parts. The result further showed that parents who are Christians have better attitude towards girlchild education than their Moslem counterparts.

Universal Basic Education Commission (UBEC) 2011/2012 report on enrolment of Junior Secondary School Students (JSS) in Sokoto State maintained that while male enrolment for JSS 1 stood at 16,704, that of female was 6,267 . For JSS 2, male enrolment was 15,759 and female was 6,318 . Enrolment for Male JSS 3 stood at 14,430 while that of female was 4,550 . Total enrolment for male was 46,893 while female was 17,135 . 


\subsection{Definition of Terms}

Attitude: Attitude in this study is defined as the behaviour of the parents toward female-child secondary education.

\subsection{Statement of the Problem}

The birth of a male child in Nigeria is often greeted with joy, happiness and jubilation than that of the female. One of the reasons is that the male child is seen as the one that would take over the responsibility of the family after the parents are gone. The female child is regarded as someone that belongs to another family because of marriage. Sometimes, the girl-child is made to hawk in order to get money to train the boy. In short, some parents have developed the attitude of sending the female child on early marriage so that they can use the money to train the boy. In the extreme northern part of Nigeria, religious belief is used to deny the female child, education. The general slogan that "the womens' place is in the kitchen" is also used to deprive the girl-child of education. The problem of this investigation, put in a question therefore, is, what kind of attitude do parents in Sokoto State have towards the female-child secondary education? The researcher then formulated one research question and one hypothesis to guide the study.

\subsection{Research Question}

1. What type of attitude do parents in Sokoto State show toward female-child secondary education?

\subsection{Hypothesis}

1. There is no significant difference between parents in the urban and rural areas in their attitude towards female-child secondary education.

\section{Research Procedure and Methodology}

The study adopted descriptive survey using Ex-post facto design. Egbule and Okobiah (2012:27) asserted that in survey study, the researcher selects samples from the population. This means that in survey study, the researcher selects samples from the population for an exploratory study to enable him discover relative incidence, distribution and interrelation of educational, sociological, psychological, political as well as economic variable.

For the purpose of this study, the state was divided into two that is, urban and rural areas. The researcher then, used purposive sampling technique to select 270 parents from the urban and 270 parents from the rural area of Sokoto State. The total number of respondents was 540 . The respondents were educated and uneducated. The researcher made use of an instrument adapted from that of Terhemba and Umaru 2015. The instrument is known as "Attitude of Parents Toward Female Child Secondary Education Questionnaire" (APTFCSEQ). The instrument consists of 15 items with a 4-point rating scale of Strongly Agree (SA) 4-points, Agree (A) 3 points, Disagree (D) 2 points and Strongly Disagree (SD) 1 point. The APTFCSEQ had reliability coefficient of 0.81 . The instrument had facial and content validity. It also had language appropriateness.

The researcher used 4 research assistants to administer 540 copies of the questionnaire on the respondents. For those who could not read and write, the research assistants read and interpreted the questionnaire to them and filled-in their responses. All the 540 copies of the questionnaire were retrieved showing 100 percent return rate. The data generated from the field were collated and the mean score analysis for the 15 items was carried out to provide answer to the research question raised in the study. 2.5 was chosen as a benchmark for either disagreeing or agreeing with each of the 15 items. The t-test was used to test the hypothesis at 0.05 level of significance. 


\section{Findings}

\subsection{Research Question}

1. What type of attitude do parents in Sokoto State show toward female-child secondary education?

Table 1: Mean Score Analysis of Parents' Attitude toward Female-Child Secondary Education in Sokoto State

\begin{tabular}{|c|c|c|c|c|c|c|c|c|}
\hline $\mathbf{S} / \mathbf{N}$ & Statement & Respondents & SA & A & D & SD & $\bar{X}$ & Decision \\
\hline 1. & $\begin{array}{l}\text { Educated male-child is more responsible than } \\
\text { educated female-child }\end{array}$ & 540 & 136 & 131 & 43 & 230 & 2.3 & Disagreed \\
\hline 2. & $\begin{array}{l}\text { Female-child should be given out in marriage and the } \\
\text { money used to provide secondary education to the } \\
\text { male-child. }\end{array}$ & 540 & 200 & 145 & 105 & 100 & 2.9 & Agreed \\
\hline 3. & $\begin{array}{l}\text { Female-child secondary education end-up in the } \\
\text { kitchen. }\end{array}$ & 540 & 85 & 150 & 104 & 201 & 2.2 & Disagreed \\
\hline 4. & $\begin{array}{l}\text { Government should give scholarship to the male-child } \\
\text { and not the female-child }\end{array}$ & 540 & 212 & 190 & 18 & 30 & 3.2 & Agreed \\
\hline 5. & $\begin{array}{l}\text { Female-child should not be given secondary education } \\
\text { because it would prevent her from marrying early. }\end{array}$ & 540 & 245 & 185 & 10 & 10 & 3.2 & Agreed \\
\hline 6. & $\begin{array}{l}\text { Money invested in female-child secondary education is } \\
\text { a waste. }\end{array}$ & 540 & 25 & 130 & 180 & 205 & 2.0 & Disagreed \\
\hline 7. & $\begin{array}{l}\text { The rate of pregnancy during female-child secondary } \\
\text { education discourages the parents. }\end{array}$ & 540 & 210 & 181 & 132 & 11 & 3.1 & Agreed \\
\hline 8. & $\begin{array}{l}\text { Providing female-child secondary education only } \\
\text { makes her a good house wife }\end{array}$ & 540 & 251 & 162 & 125 & 102 & 5.2 & Agreed \\
\hline 9. & $\begin{array}{l}\text { Female-child secondary education is good if only it is } \\
\text { free }\end{array}$ & 540 & 30 & 101 & 107 & 302 & 1.7 & Disagreed \\
\hline 10 & $\begin{array}{l}\text { It is better for a female-child to marry instead of having } \\
\text { secondary education. }\end{array}$ & 540 & 130 & 105 & 101 & 204 & 2.8 & Agreed \\
\hline 11. & $\begin{array}{l}\text { Educated female-child can contribute only little nation } \\
\text { building. }\end{array}$ & 540 & 130 & 105 & 101 & 204 & 2.8 & Agreed \\
\hline 12. & $\begin{array}{l}\text { The female-child only needs secondary education as a } \\
\text { future mother. }\end{array}$ & 540 & 252 & 173 & 125 & 105 & 3.7 & Agreed \\
\hline 13. & $\begin{array}{l}\text { Because of religious adherence, the female-child does } \\
\text { not need secondary education. }\end{array}$ & 540 & 240 & 183 & 105 & 12 & 3.2 & Agreed \\
\hline 14. & $\begin{array}{l}\text { Educated female-child does } \\
\text { not respect the parents. }\end{array}$ & 540 & 123 & 112 & 103 & 202 & 2.3 & Disagreed \\
\hline 15. & $\begin{array}{l}\text { When an educated female-child becomes married she } \\
\text { controls the husband. }\end{array}$ & 540 & 201 & 134 & 104 & 101 & 3.5 & Agreed \\
\hline \multicolumn{7}{|c|}{ Aggregate Mean Score } & 2.9 & Agreed \\
\hline
\end{tabular}

Source: Fieldwork

Table one shows the mean analysis of parents attitude toward the female-child secondary education in Sokoto State. Among the fifteen items on table one, parents showed unfavourable attitude toward female-child secondary education in ten of them. The ten items are: $2,4,5,7,8,10,11,12,13$ and 15 . The researcher found out that parents showed unfavourable attitude toward female-child education when they said that a female-child should be given out on marriage and the money be used to provide the male-child secondary education with a mean of 2.9. With the mean of 3.2 for item 4, parents showed unfavourable attitude toward female-child secondary school when they agreed that government should provide scholarship for the male-child and not the female child.

The investigation also found out that with the mean of 3.2 for item 5, parents have shown unfavourable attitude toward female-child education when they said that provision of secondary 
education to the female-child would prevent her from marrying early. The mean of 3.1 for item 7 , is a demonstration of unfavourable attitude of parents toward female-child secondary education because of the rate of pregnancy among them. The investigation has found out that parents have shown unfavourable attitude toward female-child secondary education with a mean of 2.8 on item 10 when they agreed that it is better for the female-child to marry instead of having secondary education. Parents have shown unfavourable attitude toward female-child secondary education with a mean of 3.1 on item 11 when they agreed that educated female-child only contributes little to nation building. The investigation found out that parents have shown unfavourable attitude toward female-child education with a mean of 3.7, on item 12 when they agreed that the female-child only needs secondary education as a future mother.

The investigation has revealed that parents have shown unfavourable attitude toward femalechild secondary education with a mean of 3.2 on item 13, when they agreed that because of religious adherence, the female-child does not need secondary education. The parents have also shown unfavourable attitude toward female-child secondary education when they agreed with a mean of 3.5, item 15, that an educated female-child would control the husband when she becomes married.

Parents have shown favorable attitude toward the female-child secondary education in items 1,3,6,9 and 14. In item 1, parents' showed favourable attitude toward female-child secondary education with a mean of 2.3 when they disagreed that educated male child is more responsible than educated female-child. With the mean of 2.2 for item 3, parents disagreed that female secondary education end-ups in the kitchen. The study has equally revealed that parents showed favourable attitude toward female-child secondary education with a mean of 2.0 for item 6 when they disagreed that money invested in female child secondary education is a waste. The investigation revealed that parents showed favourable attitude toward female-child secondary education when they disagreed with a mean of 1.7 on item 9 , that female-child secondary education is good if only it is free. With a mean of 2.3 , item 14, parents have showed favourable attitude toward female-child secondary education when they disagreed that educated female-child does not respect his parents.

\subsection{Hypothesis 1}

There is no significant difference between parents in the urban and rural areas in their attitude toward female-child secondary education.

Table 2: T-test of Attitude of Parents toward Female-Child Secondary Education in Sokoto State

\begin{tabular}{|c|c|c|c|c|c|}
\hline Variables & N & Df & Mean & t-cal & t-critical \\
\hline Urban & 270 & \multirow{2}{*}{538} & 24.59 & \multirow{2}{*}{1.72} & 1.96 \\
\cline { 1 - 2 } & 270 & & 30.73 & & \\
\hline
\end{tabular}

\section{Source: Fieldwork}

Table two shows a mean of 24.59 for urban and 30.75 for rural parents, a calculated $t$ of 1.72 and critical $t$ of 1.96. Since the critical $t$ of 1.96 is higher than calculated $t$ of 1.72 at 0.05 level of significant, the hypothesis which says, that there is no significant difference between parents in the urban and rural areas in their attitude toward female-child secondary education is accepted. This finding has shown that whether the parent is in urban or rural area, all of them have expressed their opinion in the same direction.

\section{Discussion}

One of the findings of this investigation is that parents have shown unfavourable attitude toward female-child secondary education. This implies that parents are not positively disposed towards the education of the girl-child at the secondary school level. This lends credence to Terhemba and 
Umaru (2015) when they found out that the attitude of parents toward girl-child enrolment, retention and completion of secondary school in Yobe State was not positive. This present study supports that of Samal in India which indicated that the attitude of parents toward girl-child education was not favourable inspite of government's endeavours in providing free education to all. The finding of Okobia and Ekejiuba in Edo State Nigeria (2015) is in contrast to the finding of the present study when they found out that parents have positive attitude toward girl-child education most especially among parents from Southern part of Nigeria residing in Benin metropolis.

Another finding of the study has revealed that there is no significant different between parents in the urban and rural areas in their attitude towards female-child Education. This result has indicated that irrespective of geographical locations, parents have unfavourable attitude towards the female-child education. This finding corroborates the study of Terhemba and Umaru (2015) when they found out that parents in urban and rural areas do not significantly differ in their attitude toward girl-child enrolment retention and completion of secondary schools in Yobe State.

\section{Conclusion}

The conclusion that can be drawn as a result of the findings is that parents in Sokoto State, Nigeria, whether living in urban or rural areas have not shown favourable attitude toward the female-child secondary education.

\section{Recommendations}

The following recommendations are made as a result of the findings and conclusion:

1. Parents in Sokoto State are advised to show favourable attitude toward female-child secondary education.

2. The Ministry of Women Affairs should organize Public Enlightenment programmes on the consequences of early marriage of girls.

3. The government should make education free up to secondary school level in the Northern part of Nigeria so that girls from poor homes can benefit.

4. Non-governmental organisation should give scholarships to girls to encourage them to learn.

5. Parents should not discriminate against their female children but rather treat all children equally and provide same opportunities for them.

6. Boys and girls should be exposed to the same socialization process so that boys will not feel more superior.

\section{Counselling Implications}

Some of the counselling implications are:

1. Counsellors are needed in secondary schools to counsel female students to model successful women in Academics in their communities and the society at large.

2. Counsellors are to organize parents' conferences and use such media to discuss with parents relevance of female education to the students themselves, their families and the nation.

3. Counsellors should counsel female students so as to build up their self-esteem and take their studies seriously.

\section{References}

Ambreen, M. and Mohyuddin, A. (2014). Gender Biased Parental Attitude toward Education, A case study of Village Dasaha District, Falsalabad, Pakistan: Academic Research International.

Egbule, J.F. and Okobiah, D.O. (2012). Research methods in education for Colleges and Universities: Agbor; Kmensuo Educational Publishers. 
Ekejiuba, P. (2011). Analysis of sex and spatial distribution of students' enrolment in secondary schools in Onitsha Educational Zone of Anambra State. African Journal of Studies in Education. 8(1) 25-32.

Federal Government of Nigeria (2016). The National Policy on Education, Lagos: Educational Research and Development Council.

Kamaldeen, A.S., Buhari, A.S. \& Parakoyi, D. (2012). Perception attitude and practices of parents in Okene Nigeria toward Girl-Child Education. International Journal of Science and Research Publication. Vol. 2, No. 8.

Okobia, E.O. and Ekujiuba, P. (2015). Parents' attitude and girl-child education in Edo State Nigeria, Rome. Journal of Educational and Social Science Research.

Olomukoro, C.O. and Omiunu, S.E. (2011). Strategies for Expanding Access to Education to the Girl-Child in Nigeria. Journal of Adult Education and Development. 5(1) 212-222.

Samal, R. (2012). Parents' attitude toward schooling and education of children. Masters Project Report. Department of Humanities and Social Sciences, National Institute of Technology, Rourkela, India

Terhemba, G.A. \& Umaru, A. (2015). Evaluation of parents attitude toward girl-child enrolment and completion of secondary school education in Yobe State, Nigeria, Counselling implications for human development, Edited by Adegoke, A.A., Aluede, O. and George, E. Counselling Association of Nigeria (CASSON).

Umoh, I.G. and Atakpa, A.O. (2014). Girl-Child Education: Changing Trends in Societal Attitudes. Multidisplinary Journal of Research Development. Vol. 22 No. 2.

Universal Basic Education Commission (UBEC) 2011/2012 Website. 